DOI 10.51558/2490-3647.2021.6.1.419

UDK 316.774:008

Primljeno: 15. 11. 2020.

Izvorni naučni rad

Original scientific paper

\author{
Mirza Mahmutović, Vedada Baraković
}

\title{
IMAGING THE NATIONAL DAY: TRACKING THE COMMEMORATION PRACTICES ACROSS VISUAL SOCIAL MEDIA SPACES
}

\begin{abstract}
This paper presents results of a preliminary study, which utilizes a hashtag-based approach and mixed-method procedures to describe the nexus between commemoration practices and visual social media. It mainly focuses on Instagram hashtags for the Day of the Republic of Srpska, a disputed and controversial public holiday celebrated on $9^{\text {th }}$ of January in the Republic of Srpska, to track how commemoration practices related to national memories are shaped through the process of digital (re)mediation.
\end{abstract}

Keywords: visual social media; commemoration; digital memories; Instagram; photography

Based on a set of approaches to social analysis referred as material semiotics (Law 2008) and the works in the field of digital memory studies (Hoskins 2018), this study explores commemoration practices afforded by visual social media. Relying on the concept of critical analytics, social media are viewed as "space for studying social issue networking” (Rogers 2018: 455). The analysis focuses on Instagram, a photo and video sharing social networking services. It is approached as an "icon and avatar for understanding and mapping visual social media cultures" (Leawer, Highfield and Abidin 2020: 2). Although recent works in the emerging interdisciplinary research subfield of "social media memory studies" (Birkner and Donk 2018) have started to explore the relationships between visual social networking sites and rituals of remembrance (Avedissian 2016; Thimm and Nehls 2017; Commane and Potton 2019; Cherasia 2020), Instagram is still underexploited resource for the study of the 
"mediatization of memory" (Hoskins 2009). The commemoration of contested past events, particularly in settings characterized by political and economic instability, history of violent conflicts and international interventions, is one such concern that deserves to be considered, investigated and addressed.

This paper presents the results of a preliminary study, which focuses on user-generated content for the Day of the Republic of Srpska, a disputed public holiday celebrated on January, $9^{\text {th }}$ in Republic of Srpska.

The controversial anniversary, set to be celebrated on this day, commemorates a founding day of the Republic of Srpska, one of two entities of Bosnia and Herzegovina. Despite the holiday being proclaimed unconstitutional by Constitutional Court of Bosnia and Herzegovina on 26th of November, 2015 and 28th of March, 2019, celebrations have taken place every year on 9th of January in the Republic of Srpska. From the beginning, commemoration of the Day of the Republic of Srpska has ushered opposing reactions among political elites and citizens of Bosnia and Herzegovina. While the majority of Bosnian Serbs in the Republic of Srpska celebrate the holiday as ,sign of pride“, other citizens, particularly returnee communities, view it as discriminatory and not representative for all ethnic groups who live in Republic of Srpska.

Previous works on the mentioned topic (Duijzings 2008; Correia 2013; Björkdahl 2018; Božić 2019) have provided important insights about the politics of memory in Republic of Srpska. However, a much less attention has been paid, if any, to forms of commemorations afforded by digital media, particularly social networking services. The presented study is an attempt to fill this research gap. The paper contributes both theoretically and empirically to the studies of digital memories in post-socialist countries.

The reminder of this article is organized in three sections. The first section presents theoretical approach and research questions guiding the study. The proposed methodology and data are explained in the second part of the paper. Finally, in the third part of article key findings of the study are given, followed by the results and discussion.

\section{THEORETICAL APPROACH AND MAIN RESEARCH QUESTIONS}

The approach taken in this study builds on the works in the field of material semiotics and digital memory studies (Garde-Hansen, Hoskins and Reading 2009; Neiger, Mey- 
ers and Zandberg 2011; Rutten, Fedoro and Zvereva 2013; Hajek, Lohmeier and Pentzold 2015; Hoskins 2018).

Drawing on the work of Pogačar, memory in digital media is understood as "a dynamic complex of thinking about, making sense of and deciphering the absences and presences (and overlaps) of represenced pasts" (Pogačar 2018: 44). Digital objects enable, he argues, several layers of connectivity, not just between users and technological devices or individuals and collectivities, but also between different temporalities and historicities. This „connectivity complex demands that we ask how the human: media (technology) entanglement structures and configures our relationship to ourselves and others and to the past, the present, and the future - in other words, how digital media technologies and our entanglement in the corporate-networked infrastructures reconfigure our being in the world"(31). In the context of this study, it is of a particular importance the notion of co-historicity, "the fragmentation of grand narratives into individual, intimate, affective renditions of past" (29).

Following this line of inquiry, digital commemoration is conceptualized as an effect of network practices that appropriate, assemble and circulate various materialsemiotic entities in order to articulate (digital) objects of remembrance. This notion also assumes existence of specific mnemonic ecologies where some sorts of interactions are cultivated and others discouraged, marginalized or eliminated as a result of dynamic (and contestable) processes of patterning.

As an object of research, national holidays have been studied extensively in the fields of social sciences and humanities. Structural approaches, particularly socialsemiotic analysis, have provided, presumably, the most elaborated conceptual framework which relates the system of national holidays (calendar) to notions of temporality, memory and social morphology. ${ }^{1}$ Put it simply, temporality and memory have been theorized with reference to functions of the social (to parse linear time) and semiotic (to memorialize the past) organization of time, two symbolic cycles which structure social experiences and relations, through the establishment of qualitative differences. „Within any given year”, as Cossu (2018) illustrates it, “the 7-day cycle (and its rhythm, with its 52 weeks and its weekly festive day) is joined by another cycle of profane and sacred days, usually marking the importance of religious holidays (Christmas, Easter) and secular dates (Independence Day, Victory Day, etc.)"(4). As a peculiar set of sacred dates organized in the form of calendar, "these

See Cossu (2018), for a general overview of the key insights of the most recent literature on national holidays, and Zerubavel (1981, 2003a, 2003b), for the elaboration of the socio-semiotic analysis of memory and temporality from the perspective of cognitive sociology. 
holidays provide an alternative rhythm, but are also instrumental in providing opportunities for celebration and for the production of discourses about national identity and belonging" (Ibid.). To further explain this phenomenon, the relationship between collective memory and political imagination, Zerubavel (1995) have suggested the notion of master commemorative narrative. The concept refers to principal stories about group's past, the memories of the community's origins and other landmark historical and mythical events, which are pivotal for formation of national identity.

Although important in the studies of national holidays, in the case of post-Dayton Bosnia and Herzegovina these influential concepts tend to conceal, if not foreclose important dimensions of commemorative dynamics underlying the media/memory field, as a result of its epistemological boundaries. As well known in the Science and Technology Studies, different epistemological positions privilege different apparatuses of observation which, in turn, condition the analytical possibility of a concept. For example, the notion of master narrative will direct, if employed as an analytic category, the attention toward three ethnically defined historical narratives that compete for hegemony and tend to prevail in public sphere. It will facilitate, presumably, understanding of post-Dayton Bosnia and Herzegovina as an indicative case of postconflict society, characterized by divided memories and permanent ethno-nationalist tensions. At the same time, it will redirect attention from the complex field of interactions that made it possible for three seemingly exclusive positions not just to coexist, produce, condition and assume each other's relevance, but also to be supported by sophisticated international arrangements. It is this field of interaction that disables (or postpones) the possibility of any particular narrative to obtain the status of master narrative, which is a necessary condition for the post-Dayton Bosnia and Herzegovina to constitute and reproduce itself as an "experimental political project" (Ćurak 2006).

Therefore, instead of taking a pre-given category as a point of departure, this study traces, maps and describes lines of (inter)actions that emerge around the issue under study, guided by the following questions:

1) How commemoration practices emerge around controversial issue - the case of $9^{\text {th }}$ January as the "foundation day" of the Republic of Srpska - on Instagram?

2) How material-semiotic resources afforded by platform - particularly in relation to hashtags network, visual content and discourses - were associated to perform (digital) commemoration? 


\section{METHODS AND DATA}

The research was designed as a preliminary study. The hashtag-based approach has been applied in order to perform an initial online issue mapping, utilizing the nexus analysis (Scollon and Scollon 2004) as methodological strategy. The study was conducted in three phases: (a) engagement with users' cultures with the aim of identifying relevant hashtag(s), (b) collection of the relevant materials on the basis of the selected hashtag, deploying a data scraper device, and (c) analysis and visualization of findings using a mixed method procedure.

To discover hashtags that are relevant to the issue under study, without any prior research to reference, it was necessary for a researcher to immerse themselves within "the nexus of the practice" (Scollon 2001). This methodological strategy encourages analysts to enter a zone of identification with key actors as a means to observe the interaction order. During the two-month period (November and December 2019), a range of tags and profiles were explored, traced and monitored to get a sense of the significant hashtags that were associated with the issue being studied. It was observed that users tend to employ a set of generic (e.g. \#republikasrpska, \#srbija, \#banjaluka, and, etc.) and issue-specific (e.g. \#9januar or \#danrepublikesrpke) hashtags. However, in terms of popularity, both groups differ undoubtedly: a significant number of posts were associated with the former then latter group. Nonetheless, the posts associated with generic hashtags tend to contain more disruptive posts, i.e. content that is not related to the issue under investigation and difficult to separate from the relevant one. On the other hand, issue-specific hashtags tend to resonate more within particular online communities and not just among majority of users concerned with the issue. The nexus analysis offers a valuable approach to complex situations such as this one. It does not presume a priori any particular settings as optimal or otherwise more suitable for the detection of the social issue being studied. It begins, as elaborated (Scollon and Scollon 2007: 619), at the point where a practice under inquiry is enacted in the experience of real social actors and builds out from there. However, while it is inevitable to start with the limited analytic perspective, it is also of crucial importance to continuously expand the "circumference of the analysis" (Scollon and Scollon 2004) in order to take into consideration broader cycles of interaction which circulate through a specific nexus of practice. Following aforementioned recommendations, the issue-specific hashtag \#9januar was selected for the analysis, due to the largest number of posts associated with it (a little more than a thousand) in comparison to other issue-specific hashtags (a less than a thousand). 
To gather data from Instagram, this study relied on Instagram Scraper, a scraping tool developed by Digital Methods Initiative. As known, there are three main digital objects in its on-screen order of existence afforded by Instagram: posts, stories and IGTV. Instagram Scraper only scrapes posts while stories and IGTV content are not included in the scrape. It might be said that this was one of the limitations of the study. ${ }^{2}$ Also, it was observed that the searches usually have to be limited up to 300 recent posts for selected hashtag(s), since larger searches tend to cause failure of the tool. Scraping was performed on the $9^{\text {th }}$ January 2020 and two days after the controversial event took place. On the $9^{\text {th }}$ January, 300 latest posts were obtained, while on the $11^{\text {th }}$ January a collection of 615 posts was collected being associated with the hashtag \#9januar (going back from 2020 to 2015). Except in the number of posts, no other significant difference was detected among these two sets. Therefore, a larger set was selected for the analysis.

To analyze and visualize findings, a variety of methods, techniques and tools was employed. A first part of the analysis was focused on the co-hashtag analysis in order to detect which hashtags were used in relation to the selected one to frame the issue. This task was performed using Gephi, a network analysis and visualization open-source software. This task was performed using Gephi, a network analysis and visualization open source software. Instagram Scraper outputs, among others available files, a GXF graphs, compatible with Gephi, which contains co-tags data (tags that appear together). Within this graph, a node represents a single hashtag and the co-occurrence of two hashtags represents an edge. The frequency of co-occurrence of two hashtags, represented as the weights of the edges, is determined by how often they appear together in the scraped posts (if the two hashtags co-occur more often, the edge is considered stronger). A network, obtained from the scraped data, consisted of 31,587 nodes and 461,996 edges. For interpretative purposes, a central node (hashtag \#9januar) was taken out of network and remaining data were filtered to achieve around the ten percent of the most connected hashtags, which resulted in a network of 332 nodes and 3107 edges. The layout algorithm ForceAtlas ${ }^{2}$ was used to spatialize network. The size and the colors of the nodes were adjusted based on the measure of the weighted degree and modularity.

The second part of the analysis investigated the content of the relevant posts $(\mathrm{N}=410)$, with an emphasis placed on the visual component of the Instagram post, and groups of users concerned with the issue. ${ }^{3}$ Using ImageSorter, an image browsing

At the moment of writing this article, Instagram Scraper tool has been deprecated, following Instagram's antiscraping measures.

Caution brought by the co-hashtags analysis, a possible presence of hashtags that might carry different meaning in different online communities, has indicated a necessity to assess data relevance before conducting a manual 
application which allows automatic arrangements of similar-looking images on the basis of color, a general overview of the relevant visuals was created in order to detect key patterns and attributes. Furthermore, to describe major themes of the imagery related to the selected hashtag, a manual content analysis was conducted. An inductive approach, informed by grounded theory's protocol of "constant comparison" (Glaser and Strauss 1967), was adopted to identify emergent categories through the procedure of open and axial coding of qualitative data. After a close reading, re-reading and constant comparison of materials, an iterative and time-consuming process, the final classification scheme was made, as presented in Table 1. Similar procedure was also applied to map the types of users.

Finally, the third part of the analysis focused on the most popular posts, in terms of number of received likes. The discourse analysis was applied to reconstruct the way in which configurations of various different entities were assembled in the form of Instagram post by certain material-semiotic relations in order to commemorate issue. A combination of nexus analysis, which maps "semiotic cycles" of heterogeneous entities involved in the social actions under study, and multimodal critical discourse analysis, which focuses on the roles played by different semiotic resources in the realization of discourses, proved to be a productive one for the analysis. Posts with more than thousand likes $(\mathrm{N}=20)$ were selected for the analysis.

As a preliminary study, this research was not designed upon statistical model of inquiry. The study aims to offer, what in ethnomethodological tradition of social research is referred as an analysis of "perspicuous instances" (Jalbert, 1999: 40): a set of situations that discerns possible patterns and principle-guided practices, in this case, regularities that characterize dynamics of digital commemoration related to visual social media cultures.

content analysis. To evaluate and separate the relevant content from the irrelevant, the visual component of the post, caption and geolocation data (if available) were considered. Visual and textual reference to the Republic of Srpska was major criteria for the inclusion of materials into further consideration. If no such associations were observed, a post was described as irrelevant. For example, a photograph depicting a person celebrating birthday at home with family, containing the caption text - "Happy Birthday to my daughter", written in German, was considered an irrelevant post although it was annotated with the hashtag \#9januar. 
Table 1. Visual content categories ( $\mathrm{N}=410)$

\begin{tabular}{|c|c|}
\hline Category & Description \\
\hline Central celebration & $\begin{array}{l}\text { Visuals associated with the central celebration of the 'Day of } \\
\text { Republika Srpska' (Banja Luka) }\end{array}$ \\
\hline Parade (20.98\%) & $\begin{array}{l}\text { Images depicting the ceremonial parade of security forces, } \\
\text { firefighters, cultural and sport groups, and other formations }\end{array}$ \\
\hline Ceremonial events ( $7.32 \%)$ & $\begin{array}{l}\text { Photos taken at high-level ceremonial events (official } \\
\text { reception, solemn academy, awards, wreath laying ceremony, } \\
\text { etc.) }\end{array}$ \\
\hline Culture and entertainment (2.20\%) & $\begin{array}{l}\text { Photographs or video depicting performances, concerts, } \\
\text { fireworks and similar events }\end{array}$ \\
\hline Religious ritual (0.49\%) & Photographs of the religious ceremony (Sv. Stefan feast day) \\
\hline Local celebrations & $\begin{array}{l}\text { Visuals related to the local celebrations of the 'Day of } \\
\text { Republika Srpska' (cities and towns in and outside Republika } \\
\text { Srpska) }\end{array}$ \\
\hline Local official ceremonies (1.95\%) & $\begin{array}{l}\text { Images taken at official ceremonies held in the cities and } \\
\text { municipalities of Republika Srpska (wreath laying ceremony, } \\
\text { commemoration practices, ceremonial assembly session, etc.) }\end{array}$ \\
\hline $\begin{array}{l}\text { Local cultural and entertainment events } \\
(1.95 \%)\end{array}$ & $\begin{array}{l}\text { Visual depicting cultural and/or entertainment events in the } \\
\text { cities and municipalities of Republika Srpska }\end{array}$ \\
\hline Unofficial celebrations (20.73\%) & $\begin{array}{l}\text { Visual depicting unofficial modes of celebration performed in } \\
\text { public (e.g. car processions with flags, gathering at squares or } \\
\text { churches, sport fan celebration practices including torches, } \\
\text { processions, flag-weaving, banners, and, etc.) and private } \\
\text { spaces (e.g. homes with flags, symbolic decorations inside } \\
\text { home settings, self-portraits at home, photographs portraying } \\
\text { family and friends). Visual depicting unusual personalized } \\
\text { forms of celebrations (e.g. mountain climbing with flags). }\end{array}$ \\
\hline Long-distance celebrations (2.44\%) & $\begin{array}{l}\text { Photographs depicting practices of long-distance celebration } \\
\text { and/or acts of support }\end{array}$ \\
\hline $\begin{array}{l}\text { Virtual greetings } \\
9^{\text {th }} \text { January greetings }(27.32 \%) \\
9^{\text {th }} \text { January anti-greetings }(1.71 \%)\end{array}$ & $\begin{array}{l}\text { Social media graphics in the form of virtual greetings } \\
\text { Greetings commemorating } 9^{\text {th }} \text { January as a national holiday } \\
\text { Greetings opposing } 9^{\text {th }} \text { January as a national holiday }\end{array}$ \\
\hline $\begin{array}{l}\text { Referendum } \\
2016 \text { Republika Srpska National Day } \\
\text { referendum (4.36\%) }\end{array}$ & $\begin{array}{l}\text { Visuals related to the Referendum on RS' national day in } 2016 \\
\text { (imagery promoting voting, photographs of the voter bails, } \\
\text { political messages, and etc.) }\end{array}$ \\
\hline \multicolumn{2}{|l|}{ Peripheral issues } \\
\hline Text-based visuals (1.71\%) & $\begin{array}{l}\text { Graphic imagery containing inspirational quotes, politicians' } \\
\text { statements, screenshot of other users' posts from Twitter and } \\
\text { similar visual forms }\end{array}$ \\
\hline Historical images (0.98\%) & $\begin{array}{l}\text { Images or screenshots of a footage recorded before or during } \\
\text { the Yugoslav wars }\end{array}$ \\
\hline Advertising (2.93\%) & $\begin{array}{l}\text { Use of photographs and/or graphics to promote or sell a } \\
\text { product or service }\end{array}$ \\
\hline Miscellaneous (2.68\%) & Miscellaneous \\
\hline
\end{tabular}




\section{FINDINGS AND DISCUSSION}

\subsection{Hashtag Analysis}

Figure 1 shows the visualization of egocentric network graph for the hashtag \#9januar. The first ten hashtags that co-occur in relation to the focal node are the following tags: \#republikasrpska, \#danrepublikesrpke, \#srbija, \#pravosljavlje, \#serbia, \#hercegovina, \#srbi, \#kosovo, \#orthodox, and \#balkan. Also, the hashtag \#banjaluka is among top three most connected nodes in the network (with the hashtags \#republikasrpska and \#danrepublikesrpke, being the first and the third one).

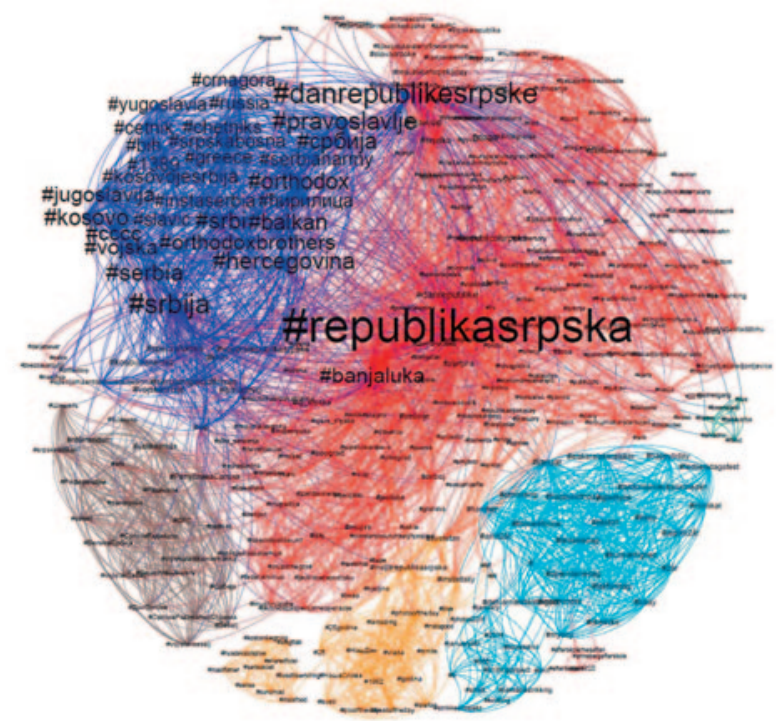

Figure 1. Egocentric network analysis (\#9januar)

According to modularity measure (resolution=1), the analysis indicates occurrence of seven clusters. Using each cluster's most connected nodes, they are referred to as a \#republikasrpska-banjaluka cluster (55.4\% of all nodes, red), a \#danrepublikesrpke\#srbija cluster (12.35\%, blue), a \#januar-\#happybirthday cluster (11.75\%, cyan), a \#svstefan-\#instadaily cluster (9.34\%, yellow), а \#РепубликаСрпска-\#velikasrbija cluster (6.93\% gray) and two minor clusters, a \#karate-\#fullcontact cluster $(2.41 \%$, pink), and \#radno-\#live cluster (1.81\%, green). The Figure 1 suggests that the first two clusters intersect noticeably. While edges between the nodes of different clusters can be observed, visualization seems to indicate that remaining clusters are consid- 
erably divergent. The cluster \#januar-\#happybirthday (and to large extent the cluster \#svstefan-\#instadaily) seems to be substantially disparate, implying a set of identical hashtags related to different semantic properties by different communities. ${ }^{4}$

\subsection{Visual Content Analysis}

At least three sets of images with similar visual patterns were observed during the initial stage of the study, selected by the automatic sorting of the entire collection of relevant imagery on the basis of color properties (see Figure 2).

\section{Virtual greetings}

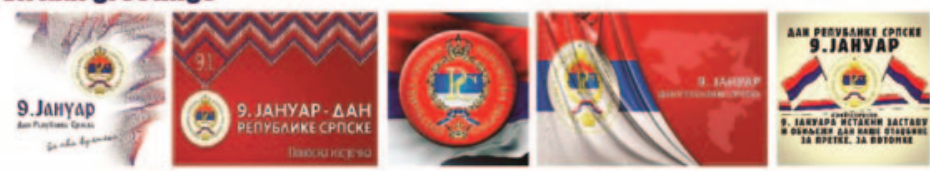

Celebration uractices tiayl

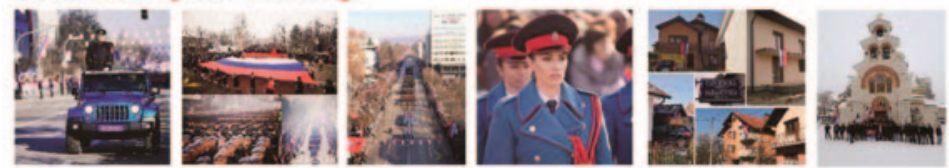

Celebration practices fnight]
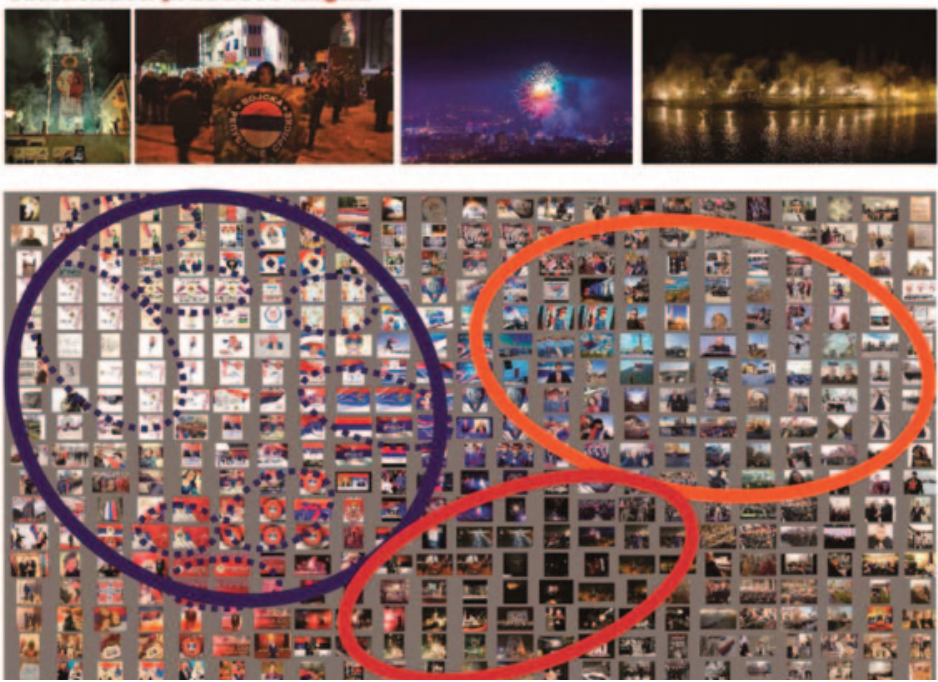

Figure 2. Preliminary visual analysis

\footnotetext{
$4 \quad$ This was later confirmed through the process of data evaluation. It was observed that the hashtag \#9januar was also employed by German-speaking and Danish-speaking users to annotate posts with content unrelated to the issue under study.
} 
The first set of images being also the most prominent one contains social media graphics in the form of virtual greetings, a particular mode of expression common to Internet culture and considerably related to meme genres. The second and the third sets of visuals depict various celebration practices, official and unofficial, occurring during the day (e.g. parade, homes decorated with flags, the group of peoples with flags in front of church, etc.) and during the night (fireworks, procession with torches, flags, banners, etc.). A preliminary overview seems to indicate that visual representations are concentrated on the events, activities and experiences occurring on and/or around the $9^{\text {th }}$ of January. Metadata records support this claim. As shown in Figure 3, the majority of the posts were created on the $9^{\text {th }}$ of January.

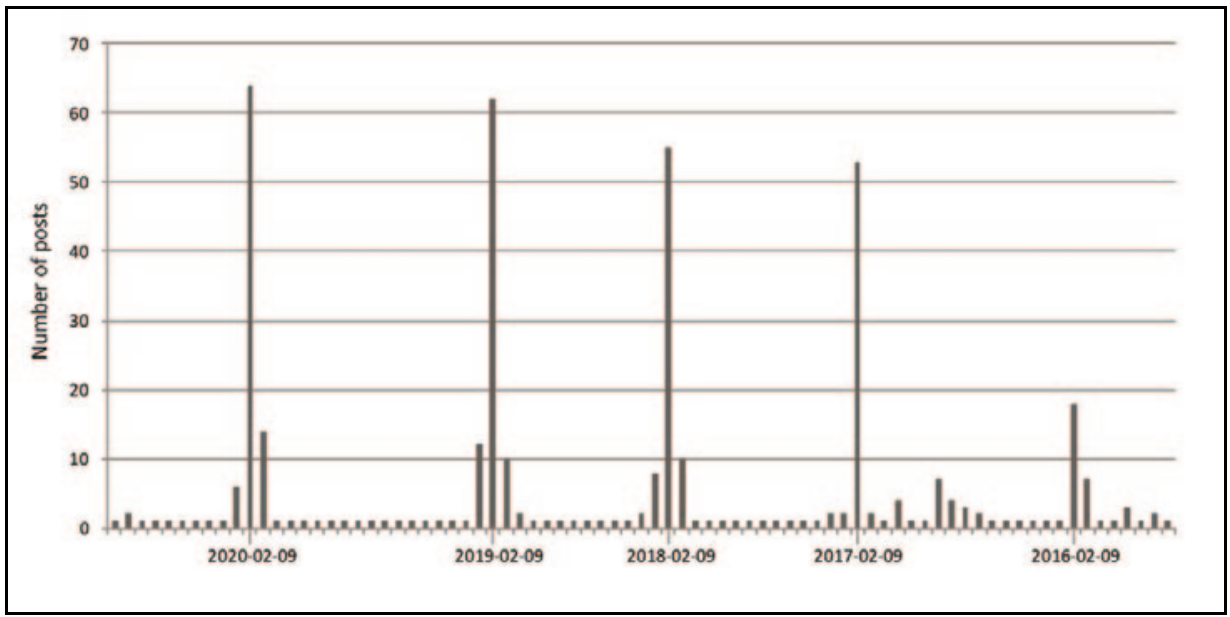

Figure 3. Posts per day (\#9 januar)

In-depth analysis of visual content has identified fifteen themes related to the hashtag \#9januar, which can be harshly classified into five subsets, as outlined in Table 1. The first three subsets encompass the majority of analyzed visuals $(87.07 \%)$. The subset here referred as central celebration is the largest one (30.98\%), followed by virtual greetings (29.02\%) and local celebrations (27.03\%). Taking into consideration individual categories of visual content, three themes stand out, here referred as 9 th January greetings (27.32\%), Parade (20.98\%), and Unofficial celebrations (20.73\%). Compared to other categories, opposing articulations, henceforth referred to as 9 th January anti-greetings were among less prominent content (1.71\% of analyzed visuals). These images linked 9th January with the Srebrenica genocide and war crimes (see Figure 4). 

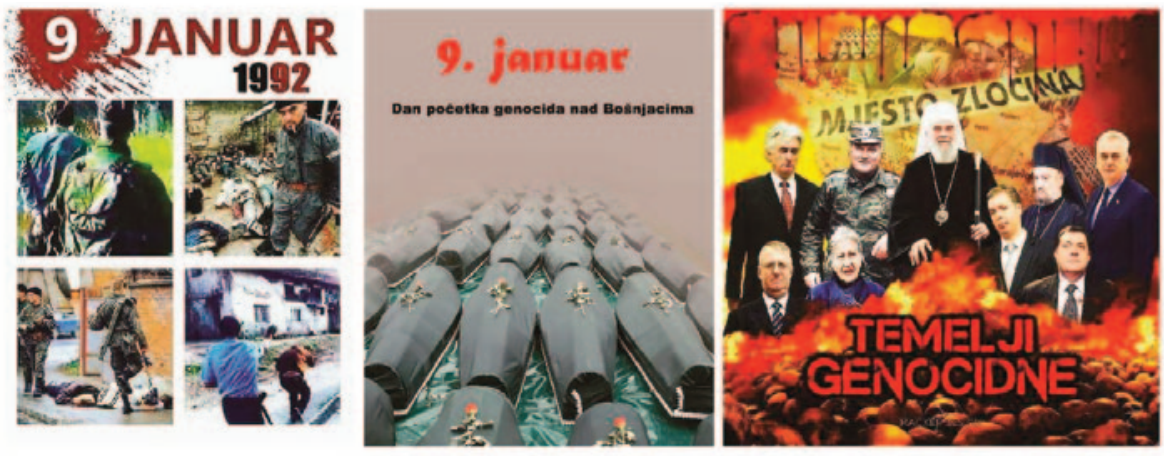

Figure 4. Examples of $9^{\text {th }}$ January anti-greetings

To describe groups of users engaged with the issue, Instagram accounts associated with scraped posts were analyzed using an inductive approach. Table 2 presents types of account and number of posts associated with them.

Table 2.: Types of account $(\mathrm{N}=410)$

\begin{tabular}{lr}
\hline Category & Number of posts (\%) \\
\hline Personal accounts & $50,29 \%$ \\
\hline Unaffiliated accounts promoting national culture (Serbian) & $13,95 \%$ \\
\hline Political parties (RS) & $6,40 \%$ \\
\hline News organizations & $6,10 \%$ \\
\hline Small businesses & $5,52 \%$ \\
\hline Governmental department (RS) & $4,07 \%$ \\
\hline Meme accounts & $2,33 \%$ \\
\hline Specific area photography (RS) & $2,03 \%$ \\
\hline Sport clubs & $1,74 \%$ \\
\hline Student's associations & $1,74 \%$ \\
\hline Folklore associations & $1,45 \%$ \\
\hline Sport content feeds & $1,16 \%$ \\
\hline Ecclesiastical organizations & $1,16 \%$ \\
\hline Unaffiliated accounts promoting national culture (Bosniaks) & $0,87 \%$ \\
\hline Non-governmental organizations & $0,58 \%$ \\
\hline Public universities & $0,58 \%$ \\
\hline
\end{tabular}

\subsection{Discourse Analysis}

According to the metadata records, a small number of posts $(4.87 \%$ of all analyzed posts) received more than a thousand likes. Almost all of the most-liked posts were published on the unaffiliated Instagram feed named srpskacast (serbianhonor) which 
publishes content promoting Serbian national identity and culture, except for one post published on the account that belongs to Nemanja Majdov, a professional judoka. Moreover, it contains images of Majdov being awarded with a medal by the President of Republic of Srpska at high-level ceremonial event that took place in Banja Luka on 9th January 2018. Analyzed contents posted on the account named srpskacast range from 2020 to 2017, containing visuals accompanied by captions written in both English and Serbian (using Cyrillic alphabet) language and accompanied by sets of hashtags.

However, this study did not manage to prove whether this profile, with more than 37 thousand followers, was linked to the right-wing group called Srbska čast (Serbian Honor). Moreover, considerable numbers of observed unaffiliated accounts with similar content were registered with usernames designated, in some version, by terms Serbian and honor. Such labeling seems to be well-recognizable and highly desirable among some groups of users. These insights point out an important aspect - online identification features of actors, which are initially defined by actors themselves, but eventually evaluated, affirmed, disputed or ignored by other users. In this process, different kind of material-semiotic resources were appropriated and integrated to achieve certain virtual identities that are acceptable within particular online communities. Referring to the analyzed account, at least three identification markers were observed: profile picture, description of the feed content, and already-mentioned username. As shown in Figure 5 profile picture was shaped in the form of seal. The center of the seal contains a white double-headed eagle, the heraldic symbol traditionally associated with the Serbian national identity, with the inscription Serbian honor (in Cyrillic) at the top and bottom, and two crosses on the left and right side. As evident, various visual (shape, color, heraldic and religious symbols) and textual (words, alphabet, fonts) elements were incorporated, assembled and realized in the form of image, presumably by a particular vector graphic software using already exited graphic resources. Reverse image search suggests, for example, that white doubleheaded eagle was adopted from one of the logos associated with fans of football club Partizan from Belgrade. The description of the feed asserts presumably the intent (Let's spread Orthodoxy), the content (Culture, Tradition, History, and Cyrillic) and the motto (I am led by the Serbian flag and the power of the cross), using Cyrillic alphabet and two emoji representing Serbian flag. Selected linguistic entities are linked, as can be seen, to group-specific values utilizing catchy taglines, short textual forms privileged by the platform, not just to summarize and attract attention to the feed, but also to express certain kinds of commitments, if not ideological alignment. All three 
markers, profile picture, description and name, including technologies underlying their production and dissemination, provided significant conditions for identity performance to occur.

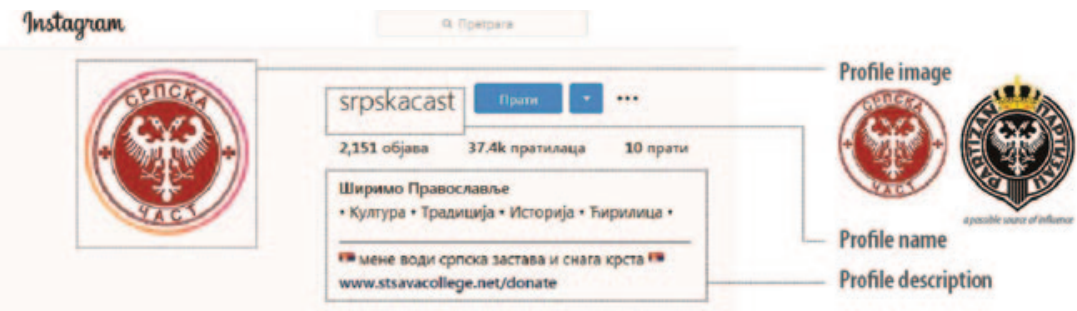

Figure 5. Identification markers

Commemoration of a significant anniversary, in this case $9^{\text {th }}$ January as the foundation day of the Republic of Srpska, is accomplished through the act of sharing: posting of the selected content at a chosen time on the account. Although they might appear, at least at first sight, as extremely simplified accounts of past events, and a result of superficial engagement with the issue, the analysis indicates that most-liked posts are the end product of a much more complex work, in which diverse materialsemiotic resources, featuring multiple modes, historical references, religious imagery, temporalities, genres, technologies and other entities are deployed, organized and translated into a form of digital object, not just to establish intended meanings, but also to enable mobility, availability and accessibility of created contents across platforms (i.e. sharing, storing and editing practices).

The analysis of posts' properties discerns a specific posting pattern and a limited set of objects consistently employed over time to mark the controversial anniversary. Three different posts, all being among the ten most-liked, were particularly salient (see Figure 6). These posts, once published, were actualized annually, appearing sequentially one after another in the feed with unaltered content. The post with the image of a soldier kissing the flag (henceforth referred to as The first post) was generally published first, followed by the post featuring religious imagery and the map representing the territory of the Republic of Srpska (henceforth referred to as The Second Post) and the post with the image of two armed policemen positioned in front of the cross, flag and maps of the Republic of Srpska and Serbia (henceforth referred to as The Third Post). Occasionally, the content produced by other users, mostly a video footage depicting sport fan celebration practices that tied in with the 9th January anniversary, was included in the feed to supplement republished posts. 

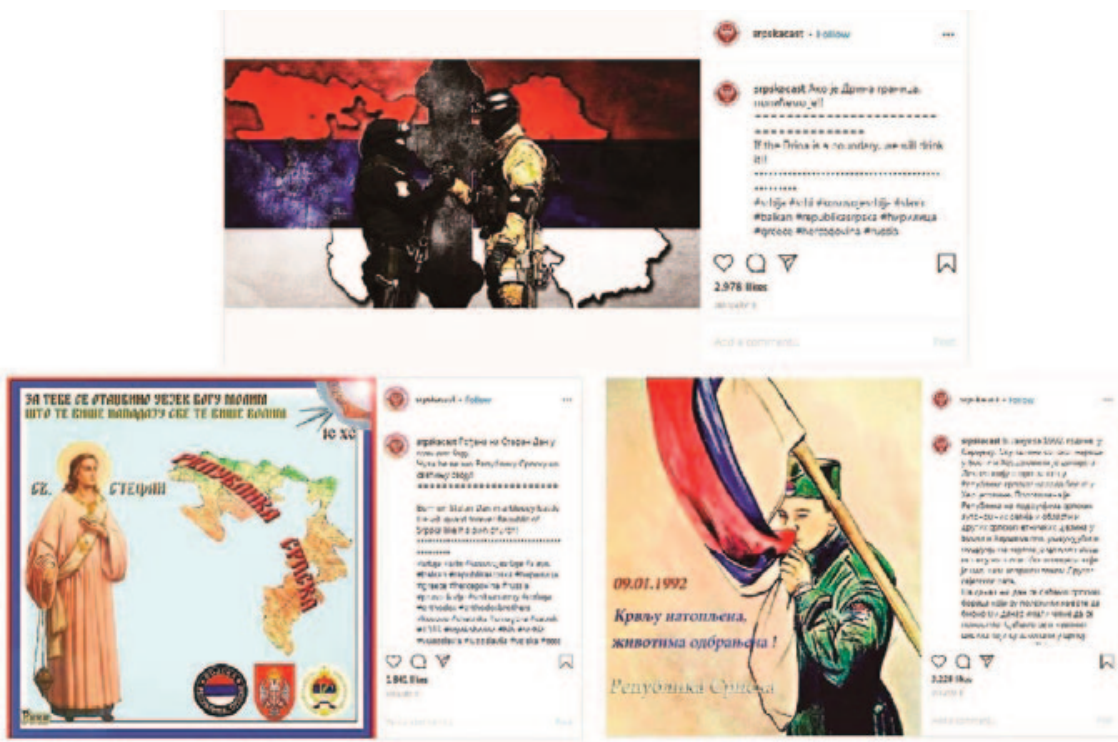

Figure 6. Examples of most-liked posts

The recurring posts manifest a set of entities associated together in specific ways to communicate, particular types of discourses. In this process different kind of material-semiotic resources, each with different affordances, were employed to establish certain sort of connections through social media objects and to discard other sorts of connections. In the first post, for example, various threads - graphic imagery, body gesture, inscriptions, fonts, colors, alphabets, languages, figures of speech, grammatical forms, vocabularies, narratives, historical references, sources, metadata tags, graphic manipulation devices, and others entities - were woven, juxtaposed and arranged into social media format in order to perform commemorative work. The visual component of the post suggests an image and idea of patriotism, utilizing at least three elements - the figure of soldier, identified only by military cloth badges, an emotional body gesture, and the flag representing political entity - which were designed, intentionally or not, using diagonal lines as a dominant direction in the composition, neutral background to enhance figure-ground relationship, and the square format, as the original aspect ratio for visual content on Instagram. Textual inscription relates to a date from history (1/9/1992), the account of reportedly past events and experiences (Soaked in blood, defended by lives!) and the name of political entity (Republic of Srpska), employing Cyrillic alphabet, cursive-based font and three symbolic colors. The inscription displayed in the middle seems to evoke concepts of sac- 
rifice, threat, defense, and victory, deploying the corporeal and biological attributes. The passive construction of the statement is indicative. It implies both the agent (defenders and/or attackers) and the recipient of actions, but avoids their naming. However, references provided by other elements (the inscription of the name and the image of a soldier) tend to suggest their identity, with the exception of the implied "attacker", who is assumed only as dangerous other. Features of multiple genres, such as illustration, greetings, poster, and internet meme, seem to be combined together to enable the whole set of such relations to be constituted and expressed in an imaginable form.

The visual component of the second post reiterates previous references to patriotism and existential threat. Furthermore, it also transposes them to the present-day world deploying the inscription written in Cyrillic alphabet, featuring religious vocabulary and patterns of rhymes (Za tebe se otadžbino uvijek Bogu molim, što te više napadaju sve te više volim, which could be literally translated as For you fatherland I always pray to God, the more you have been attacked, the more I love you). The religious imagery associated with the post (the icon of St. Stephen and a Christogram) is accompanied by a caption which relates a political entity (Republic of Srpska) to a holy object (Born on Stefan Dan in a bloody battle, He will guard forever Republic of Srpska like his own church!).

Religious imagery is also a prominent part of the visual component of the third post. It consists of several layers, a figure of two policemen, an orthodox cross, redblue-white tricolor and the map representing territories of the Republic of Srpska and Serbia. Visual features, such as size, position, and colors of the forms, and an image editing software, were used to connote particular meaning. The design of the image tends to suggest that the cross is the central, if not unifying, element of all other associated layers. Its position on the map, lying on the boundary between Bosnia and Herzegovina and Serbia, is also indicative. Similarly, the red-blue-white tricolor seems to blend rather than separate the territories of two internationally recognized states. The image of two policemen, each wearing different uniforms and positioned in front of one of two territories and with the symbolic body gesture, tends to suggest a sense of special bonding, if not brotherhood. Moreover, reverse image search indicates that this image was adopted from one of the photographs capturing a joint exercise called Drina 2013 by policemen from Serbia and the Republic of Srpska. The caption associated with described configuration of visual entities problematizes, if not discards, the river Drina as a boundary with the reference to an unnamed collective actor (If the Drina is a boundary, we will drink it!). This seems to evoke an idea of territorial and national unity. 


\subsection{Discussion}

Correia has pointed at three prominent features of the politics of memory in the Republic of Srpska. It is characterized by (a) presenting the recent war as defensive (Defensive-Fatherland War), (b) inducing a sense of continuity between the recent conflict and earlier experiences of oppression (particularly the Second World War), and (c) relativising the suffering of non-Serb victims through the idea that all sides were guilty (Correia 2013: 349). The interaction order emerged around an issue space related to the hashtag \#9januar seems to reiterate and supplement these politics of memory. In these processes various material-semiotics entities were associated to enable a particular action, commemoration, to take place within (digital) media spaces. Digitally-mediated commemoration practices tend to generate, as evident in the case of the three most prominent themes of visual contents and popular posts, simplified, individual and mostly affective renditions of past.

The analysis also draws attention to less prominent features of commemorative dynamics. Here, at least two insights deserve a close consideration: the scarcity of historical images and the marginal status of contesting accounts. The results indicate that the historical images were rarely employed as a commemorative device, which is surprising, given the general context of commemorative culture. Does this suggest the lack of iconic images depicting the "founding event", the avoidance of potentially harmful references to "founding fathers" and their war crimes legacy, the prevalence of contemporary concerns, or something else? These questions remain to be addressed by future research. Unlike other domains, political, journalistic or academic field, where the celebration of this anniversary tends to trigger heated debates about recent past, the group that emerged around issue space on Instagram appears to be more a like-minded community, at least in this case.

Furthermore, it is important to consider the limitations and opportunities of the hashtag-based approach. As previously mentioned, a small number of posts were associated with the hashtag \#9januar, which is an important caution to bear in mind. Also, the attention should be paid to the ambiguity of hashtag usages. In order to overcome these limitations, future research should consider and compare other issuespecific hashtags, utilizing mixed-method procedures. Without a comparative analysis in hashtag approach, it is rather difficult to discern what kinds of networks have emerged within an issue space. Our study raises the questions whether commemoration practices afforded by Instagram are effects of a small network (as this analysis seems to suggest) or on the other hand online community concerned with the issue is 
larger but hard to detect because the possibility to trace its engagement was minimized (private profiles, removal of posts, unannotated posts, etc.)?!

Overall, this study indicates the complex, mutually constitutive relationship between political performances (rhetorical politics, commemoration rituals, historical narratives, etc.) and mundane, everyday mediated actions (recording, sharing, editing, etc.), both marked by an affective stance. Preliminary findings seem to support the proposal (Jerne 2017) to analyze the potential of memory not just as an identity-shaping, but also as a mobilizing force. It is believed that visual and photography studies offer a useful approach to tackle the role of visual social media platforms in these processes. Thus, it is essential to emphasize and recommend the works of Tagg (2009, 1989), Frosh and Pinchevski (2009, 2014). Tagg has described, in his analysis of the New Deal strategy of crisis management, how the photographic apparatus was mobilized - as a mean of recruitment of certain political subjectivity - in the service of state intervention. Frosh and Pinchevski suggested the concept of "media witnessing", witnessing performed in, by, and through the media, to capture dynamics being central to the practice of contemporary media. One cannot ask, looking through these conceptual lenses, if the media witnessing afforded by the ubiquitous mobile audiovisual devices and social networks is a new-old way of recruitment of subjects as ethnic citizens, "called to witness, called to reality and coherence, precisely at a time when the established regimes of sense and sociality were profoundly threatened by a crisis“(Tagg, 2009: 28)?!

\section{REFERENCES}

1. Avedissian, Karena (2016), "Clerics, weightlifters, and politicians: Ramzan Kadyrov's Instagram as an official project of Chechen memory and identity production", Caucasus Survey 4:1, 20-43.

2. Birkner, Thomas, Andre Donk (2018), "Collective memory and social media: Fostering a new historical consciousness in the digital age?", Memory Studies 13(4), 367-383.

3. Björkdahl, Annika (2018), "Republika Srpska: Imaginary, performance and spatialization", Political Geography 66, 34-43.

4. Božić, Gordana (2019), "Diversity in ethnicization: War memory landscape in Bosnia and Herzegovina“, Memory Studies 12(4), 412-432.

5. Cherasia, Spencer P. (2020), "Affordances, remediation, and digital mourning: A comparative case study of two AIDS memorials", Memory Studies. 
6. Commane, Gemma, Rebekah Potton (2019), "Instagram and Auschwitz: a critical assessment of the impact social media has on Holocaust representation", Holocaust Studies 25:1-2, 158-181.

7. Correia, Sarah (2013), "The Politics of Memory in Bosnia's Republika Srpska",u Listhaug, Ola, Ramet, Sabrina ur., Bosnia-Herzegovina since Dayton: Civic and Uncivic Values, Longo Editore, Ravenna, 329-350.

8. Cossu, Andrea (2018), "From lines to networks: Calendars, narrative, and temporality“, Memory Studies 13(4), 502-518.

9. Ćurak, Nerzuk (2006), Obnova bosanskih utopija: politička filozofija, politologija i sociologija postdejtonske BiH, Synopsis, Sarajevo-Zagreb

10. Duijzings, Ger (2008), "Commemorating Srebrenica: Histories of Violence and the Politics“, u: Bougarel, Xavier, Helms, Elissa \& Duijzings, Ger (ur.), The New Bosnian Mosaic: Identities, Memories, and Moral Claims in o PostWar Society, Ashgate Publishing Company, Aldershot-Burlington, 141-166.

11. Frosh, Paul, Amit Pinchevski (ur.) (2009), Media Witnessing: Testimony in the Age of Mass Communication, Palgrave Macmillan, Houndmills

12. Frosh, Paul, Amit Pinchevski (2014), "Media witnessing and the ripeness of time“", Cultural Studies 28:4, 594-610.

13. Garde-Hansen, Joanne, Andrew Hoskins, Anna Reading (ur.) (2009), Save As ... Digital Memories, Palgrave Macmillan, New York

14. Glaser, Barney G., Anselm L. Strauss (1967), The Discovery of Grounded Theory: Strategies for Qualitative Research, Aldine Publishing Co, Chicago

15. Hajek, Andrea, Christine Lohmeier, Christian Pentzold (ur.) (2015), Memory in a Mediated World: Remembrance and Reconstruction, Palgrave Macmillan, Basingstoke

16. Hoskins, Andrew (2009), "The mediatization of memory“, u: Garde-Hansen, Joanne, Andrew Hoskins, Anna Reading (ur.), Save As ... Digital Memories. Palgrave Macmillan, New York, 27-43.

17. Hoskins, Andrew (ur.) (2018), Digital Memory Studies. Media Pasts in Transition, Routledge, New York

18. Jalbert, Paul L. (1999), "Critique and Analysis in Media Studies: Media Criticism as Practical Action”, u Jalbert, Paul L. (ur.), Media Studies: Ethnomethodological Approaches, University Press of America, Lanham

19. Jerne, Christina (2020), "Event-making the past: Commemorations as social movement catalysts“, Memory Studies 13(4), 486-501. 
20. Law, John (2008), "Actor network theory and material semiotics", u: B. S. Turner (ur.), The new Blackwell companion to social theory, Wiley-Blackwell, Oxford, 141-158.

21. Leawer, Tama, Tim Highfield, Crystal Abidin (2020), Instagram. Visual Social Media Cultures, Polity, London

22. Machin, David (2013), "What is Multimodal Critical Discourse Studies?", Critical Discourse Studies 10 (4), 347-355.

23. Neiger, Motti, Oren Meyers, Eyal Zandberg (ur.) (2011), On Media Memory: Collective Memory in a New Media Age, Palgrave Macmillan, Basingstoke.

24. Pogačar, Martin (2018), "Culture of the Past: Digital Connectivity and Dispotentiated Futures”, u: Hoskins, Andrew (ur.), Digital Memory Studies. Media Pasts in Transition, Routledge, New York

25. Rogers, Richard (2018), "Otherwise Engaged: Social Media from Vanity Metrics to Critical Analytics", International Journal of Communication 12, 450-472.

26. Rutten, Ellen, Julie Fedor, Vera Zvereva (ur.) (2013), Memory, Conflict and New Media Web Wars in Post-Socialist States, Routledge, New York.

27. Scollon, Ron (2001), Mediated Discourse. The nexus of practice, Routledge, New York

28. Scollon, Ron, Suzanne Wong Scollon, (2004), Nexus Analysis: Discourse and the Emerging Internet, Routledge, New York

29. Scollon, Ron, Suzanne Wong Scollon Wong (2007), "Nexus Analysis: Refocusing Ethnography of Action", Journal of Sociolinguistics 11(5), 608-625.

30. Tagg, John (1989), „The Currency of the Photograph“, u: Burgin, Victor (ur)., Thinking Photography, Macmillan, Basingstoke, 110-141.

31. Tagg, John (2009), „Mindless Photography“, u: Long, J. J, Andrea Noble, Edward Welch (ur.), Photography. Theoretical Snapshots, Routledge, New York, 16-32.

32. Thimm, Caja, Patrick Nehls (2017), "Sharing grief and mourning on Instagram: Digital patterns of family memories", Communications 42 (3), 327-349.

33. Zerubavel, Eviatar (1981), Hidden Rhythms, University of California Press, Berkeley

34. Zerubavel, Eviatar (2003a), "Calendars and history: a comparative study of the social organization of national memory“", u: Olick, Jeffrey (ur.), States of Memory: Continuities, Conflicts, and Transformations in National Retrospec tion, Duke University Press, Durham, 315-337. 
35. Zerubavel, Eviatar (2003b), Time Maps, University of Chicago Press, Chicago.

36. Zerubavel, Yael (1995), Recovered roots: Collective memory and the making of Israeli national tradition, The University of Chicago Press

\title{
UPRIZORENJE NACIONALNOG DANA: PRAĆENJE KOMEMORATIVNIH PRAKSI U PROSTORIMA VIZUELNIH DRUŠTVENIH MEDIJA
}

\section{Sažetak:}

Rad predstavlja rezultate preliminarne studije, koja se koristi hashtag analitičkim pristupom i mješoviti istraživačkim postupcima, kako bi opisala spone između komemorativnih praksi i vizuelnih društvenih medija. Studija se usmjerava na društvenu mrežu Instagram i koristi slučaj „Dana Republike Srpske“, kontroverznog praznika koji se obilježava devetog januara u Republici Srpskoj, kako bi pratila kako se komemoracijske prakse povezane s nacionalnim memorijama oblikuju kroz proces digitalne (re)medijacije.

Ključne riječi: vizualni društveni mediji; komemoracija; digitalne memorije; Instagram; fotografija.

\author{
Adresa autora \\ Authors' address \\ Mirza Mahmutović \\ Vedada Baraković \\ University of Tuzla \\ Faculty of Humanities and Social Sciences \\ mirza.mahmutovic@untz.ba \\ vedada.barakovic@untz.ba
}


